\title{
An influence of slag refining on the structure and mechanical properties of the brass $\mathrm{CuZn} 39 \mathrm{~Pb} 2$
}

\author{
Mariusz Jenek $^{1}$ (D) Paweł Schlafka ${ }^{1}$ \\ Received: 23 January 2021 / Accepted: 20 May 2021 / Published online: 1 June 2021 \\ (C) The Author(s) 2021
}

\begin{abstract}
The results presented in the dissertation show the influence of a kind and concentration of the flux added during the process of the lead brass smelting on its structure, chemical composition and mechanical properties - hardness and strength. A positive refining, structure, mechanical properties, brass influence of the refining and modification process manifested in an improvement of mechanical properties as well as an increase of the structure, chemical composition and mechanical properties homogeneity in the entire volume of the ingot has been proven. The influence of the flux concentration on the structure and mechanical properties of the alloy was determined. The optimal flux concentration improving the tested properties was established.
\end{abstract}

Keywords Refining $\cdot$ Structure $\cdot$ Mechanical properties $\cdot$ Brass

\section{Introduction}

Due to its properties, brass is one of the most popular alloys. In the work [1-3], special properties of the $\mathrm{CuZn39Pb2}$ alloy have been noticed. They are special in terms of such characteristics as mass, wear resistance, good formability and high thermal conductivity. This alloy is the most frequently used in the machining processes. It has exceptional properties in reference to stresses in moulding. Nowadays, refining and modifying play the crucial role in the production of metals and alloys of good mechanical properties [1, 2, 4-6]. In the work [7], the influence of the $\mathrm{CuZn} 39 \mathrm{~Pb} 2$ alloy plastic forming on its mechanical properties has been presented. The research has shown that lead is almost insoluble in $\mathrm{Cu}$ alloys. It is used to improve brass machinability. Lead may contribute to the deterioration of the brass ductility in low and high temperatures. Brass and its alloys belong to materials which can be recovered (from post-production wastes or scrap). Depending on the purity level of the copper alloy and its chemical

Mariusz Jenek

m.jenek@iim.uz.zgora.pl

Paweł Schlafka

p.schlafka@iim.uz.zgora.pl

1 Faculty of Mechanical Engineering, University of Zielona Góra, ul. Licealna 9, 65-417 Zielona Góra, Poland composition, it may be melted directly or it must be refined and modified in the melting process $[1,6]$. In the work, it has been indicated that refinement and modification processes in brass should be conducted in order to form the structure and the properties.

Modifying metals and their alloys with microadditions of selected elements enables a positive impact on a primary structure of alloys made in a process of solidification. The studies of the authors $[1,8,9]$ have shown a significant complexity of the brass alloys modification processes. On account of the environmental protection $[1,6,9]$, to reduce the amount of harmful substances emerged in the refining and modification process, an attempt to intensify the impact of chemical substances on an alloy by their appropriate selection should be made $[1,6]$.

In the work [10], it has been shown that the changes in brass structure such as inclusions and precipitates on the grain boundaries are the reason of the ductility decrease. Analyses performed in the work [11] have proven that changes in the $\mathrm{CuZn39Pb}$ alloy structure and conditions of the research are the most frequent factors influencing its wear.

\section{Research methodology}

In the research, the copper $\mathrm{CuZn} 39 \mathrm{~Pb} 2$ has been used. Its chemical composition, in accordance with the standard, has been presented in Table 1 . 
Table 1 Chemical composition the brass $\mathrm{CuZn} 39 \mathrm{~Pb} 2$

\begin{tabular}{lllllllll}
\hline Chemical element & $\mathrm{Cu}$ & $\mathrm{Al}$ & $\mathrm{Fe}$ & $\mathrm{Ni}$ & $\mathrm{Sn}$ & $\mathrm{Pb}$ & $\mathrm{Zn}$ \\
\hline Contents [\%] & $59-60$ & $<0.05$ & $<0.3$ & $<0.3$ & $<0.3$ & $1.6-2.5$ & Rest
\end{tabular}

In the research, the Topbal $\mathrm{Z}$ flux has been used. Topbal Z is boron-based flux, developed in the factory. There have been three smelts corresponding to the concentration:

- Without any flux

- $0.1 \%$ of the kiln charge

- $0.15 \%$ of the kiln charge

The smelting has been proceeded in industrial conditions in Radyne 1500 coreless induction furnace. The feedstock was the process scrap from the material removal processing, containing the cooling lubricant. The single kiln charge was 1200 $\mathrm{kg}$.

The places in the smelt where the samples for the research have been cut out from have been presented in Fig. 1.

The structure of prepared microsections has been examined by an optical microscope AXIO Observer A1m in six zones with zooms $50-1000 x$. The quantitative and qualitative research has been done on the scanning microscope JSM-5600LV by JEOL, equipped with a EDS 2000 X-ray analyser by IXRF SYSTEMS.

The strength tests of samples from the particular smelts have been done on a fatigue testing system INSTRON 8802, on samples cast to die casting moulds. Hardness of particular samples has been determined on the Zwick/Roel ZHV10 hardness tester with load of $200 \mathrm{~g}$.

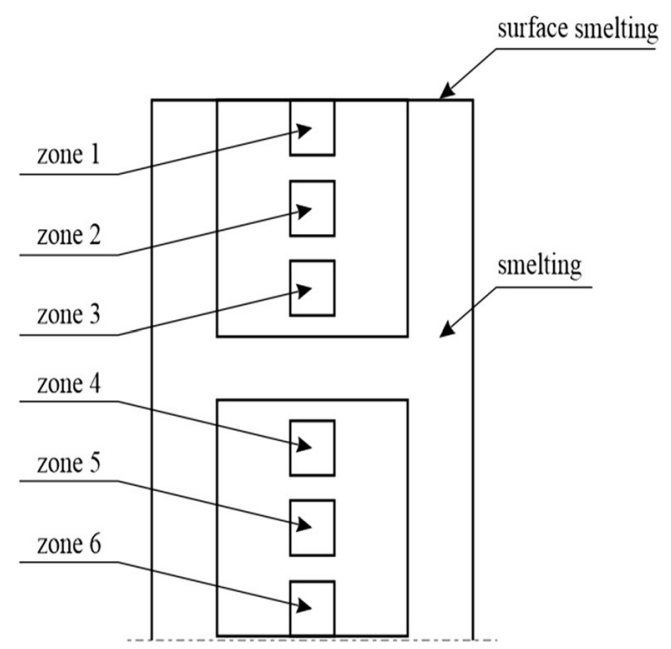

Fig. 1 Places of taking samples from the smelt

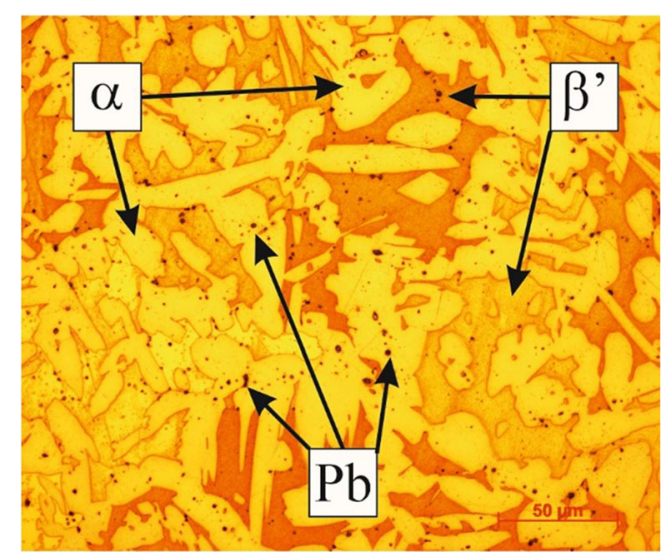

Fig. 2 Sample structure of the alloy $\mathrm{CuZn} 39 \mathrm{~Pb} 2$

\section{The research results}

An example of the alloy structure with a description of the phases is shown in Fig. 2. The research of the refining influence on the brass structure has given the results shown in Fig. 3, illustrated by examples of selected images of chosen zones. The microstructure

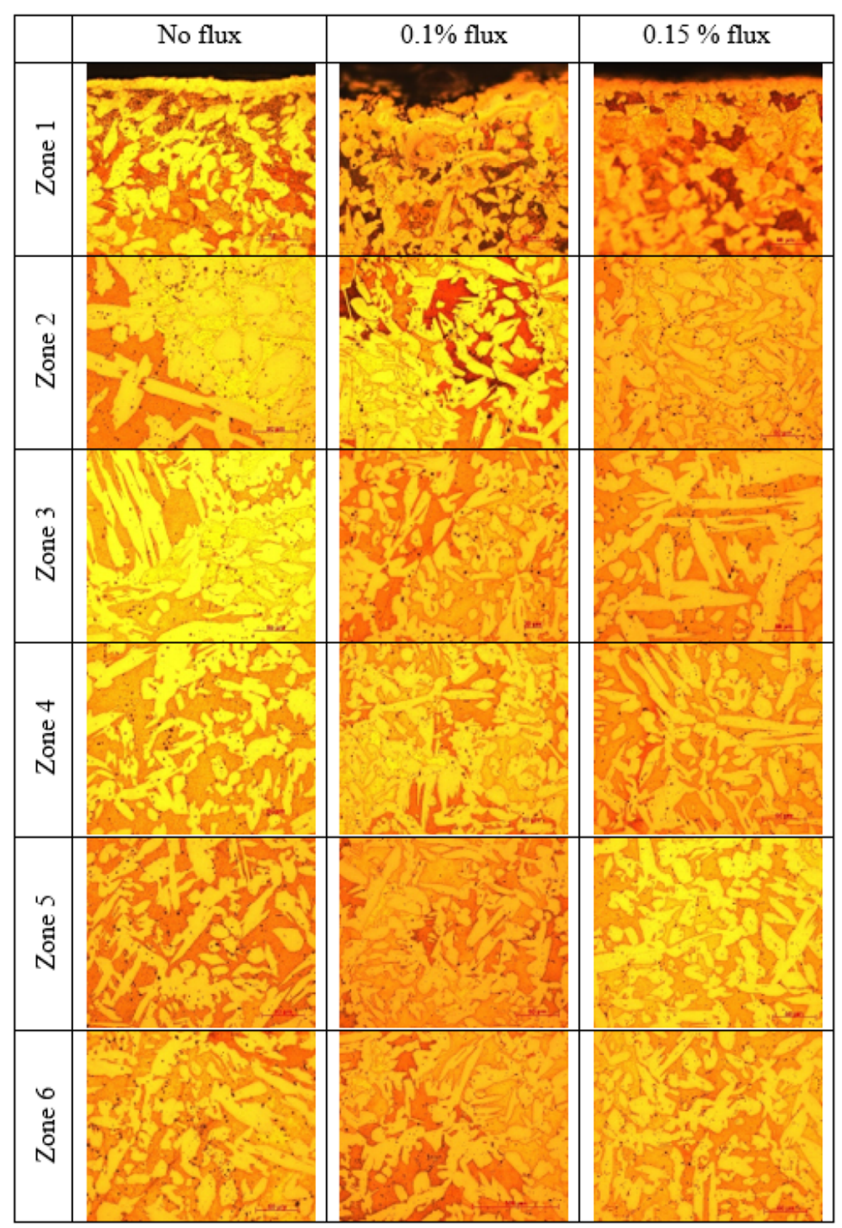

Fig. 3 The metallographic structures of the samples in the selected zones (chemical etching of $\mathrm{Mi} 18 \mathrm{Cu}$ ) 


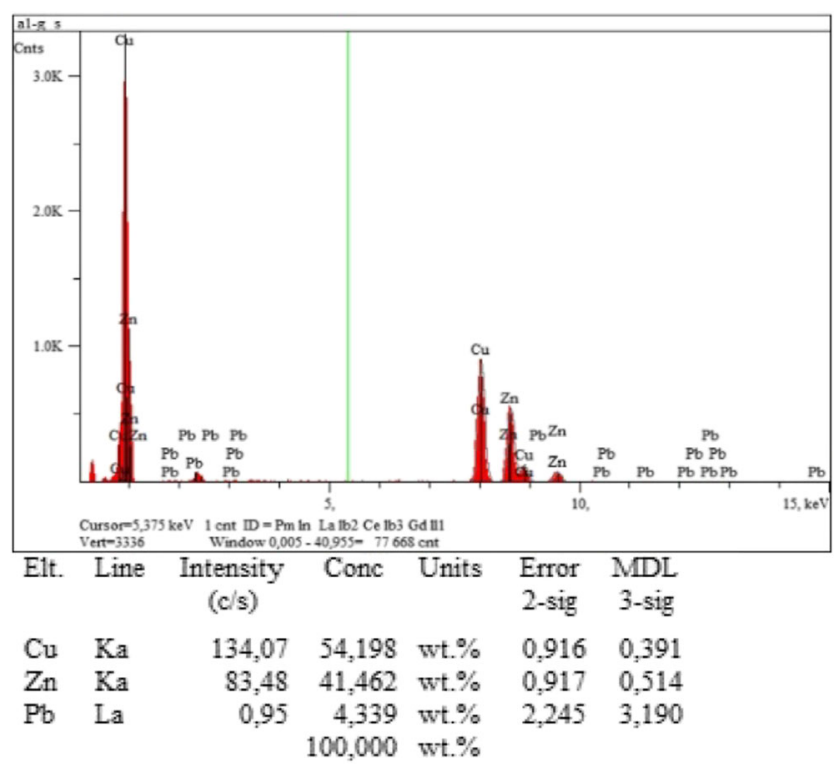

$\mathrm{kV}$ 20,0

Takeoff Angle $35,0^{\circ}$

Elapsed Livetime 113,1

Fig. 4 Analysis of the chemical composition of the sample from smelt without flux, zone 1

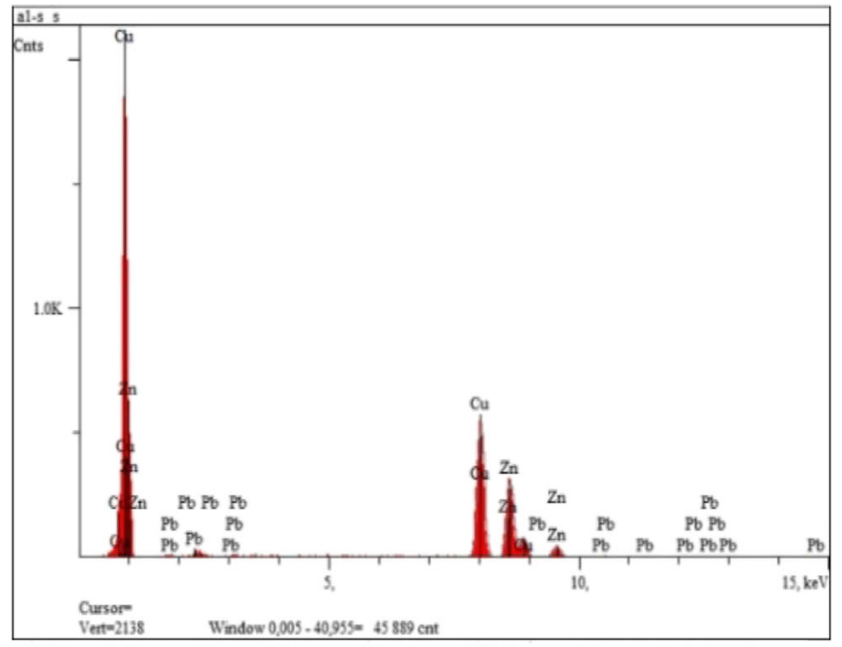

$\begin{array}{llrrrrr}\text { Elt. } & \text { Line } & \begin{array}{c}\text { Intensity } \\ (\mathrm{c} / \mathrm{s})\end{array} & \text { Conc } & \text { Units } & \begin{array}{c}\text { Error } \\ 2 \text {-sig }\end{array} & \begin{array}{c}\text { MDL } \\ 3 \text {-sig }\end{array} \\ & & & & & \\ \mathrm{Cu} & \mathrm{Ka} & 155,30 & 56,925 & \text { wt. } \% & 1,224 & 0,522 \\ \mathrm{Zn} & \mathrm{Ka} & 86,94 & 39,114 & \text { wt. } \% & 1,163 & 0,660 \\ \mathrm{~Pb} & \mathrm{La} & 0,96 & 3,961 & \text { wt. } \% & 2,851 & 4,063 \\ & & & 100,000 & \text { wt. } \% & & \end{array}$

$\mathrm{kV} \quad 20,0$

Takeoff Angle $\quad 35,0^{\circ}$

Elapsed Livetime 60,4

Fig. 5 Analysis of the chemical composition of the sample from smelt without flux, zone 2

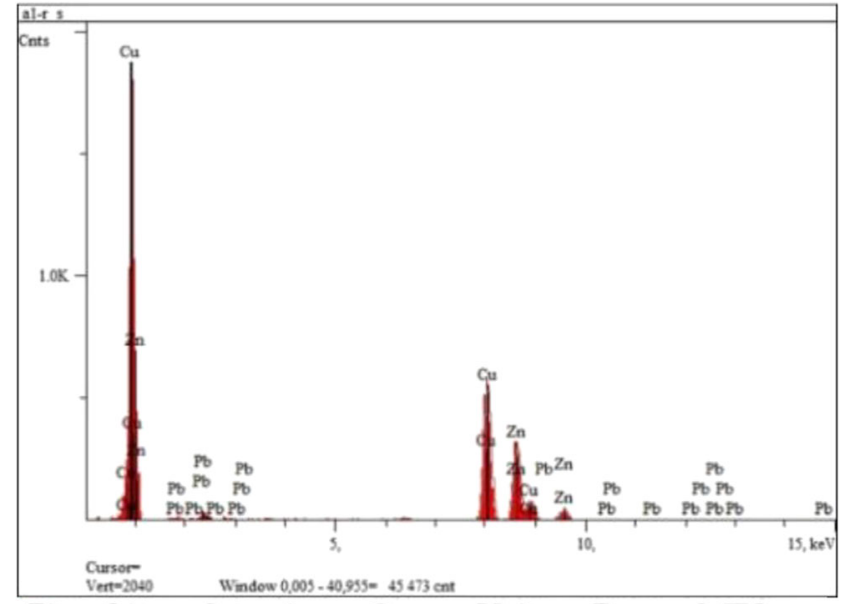

\begin{tabular}{|c|c|c|c|c|c|}
\hline Elt. Line & $\begin{array}{c}\text { Intensity } \\
\text { (c/s) }\end{array}$ & Conc & Units & $\begin{array}{l}\text { Error } \\
2 \text {-sig }\end{array}$ & $\begin{array}{r}\text { MDI } \\
\text { 3-sig }\end{array}$ \\
\hline $\mathrm{Ka}$ & 155,08 & 56,919 & wt. $\%$ & 1,222 & 0,512 \\
\hline $\mathrm{Ka}$ & 88,76 & 40,008 & wt. $\%$ & 1,170 & 0,644 \\
\hline $\mathrm{La}$ & 0,74 & $\begin{array}{r}3,073 \\
100,000\end{array}$ & $\begin{array}{l}\text { wt. } \% \\
\text { wt. } \%\end{array}$ & 2,675 & 3,846 \\
\hline
\end{tabular}

$\mathrm{kV} \quad 20,0$

Takeoff Angle $35,0^{\circ}$

Elapsed Livetime 60,5

Fig. 6 Analysis of the chemical composition of the sample from smelt without flux, zone 3

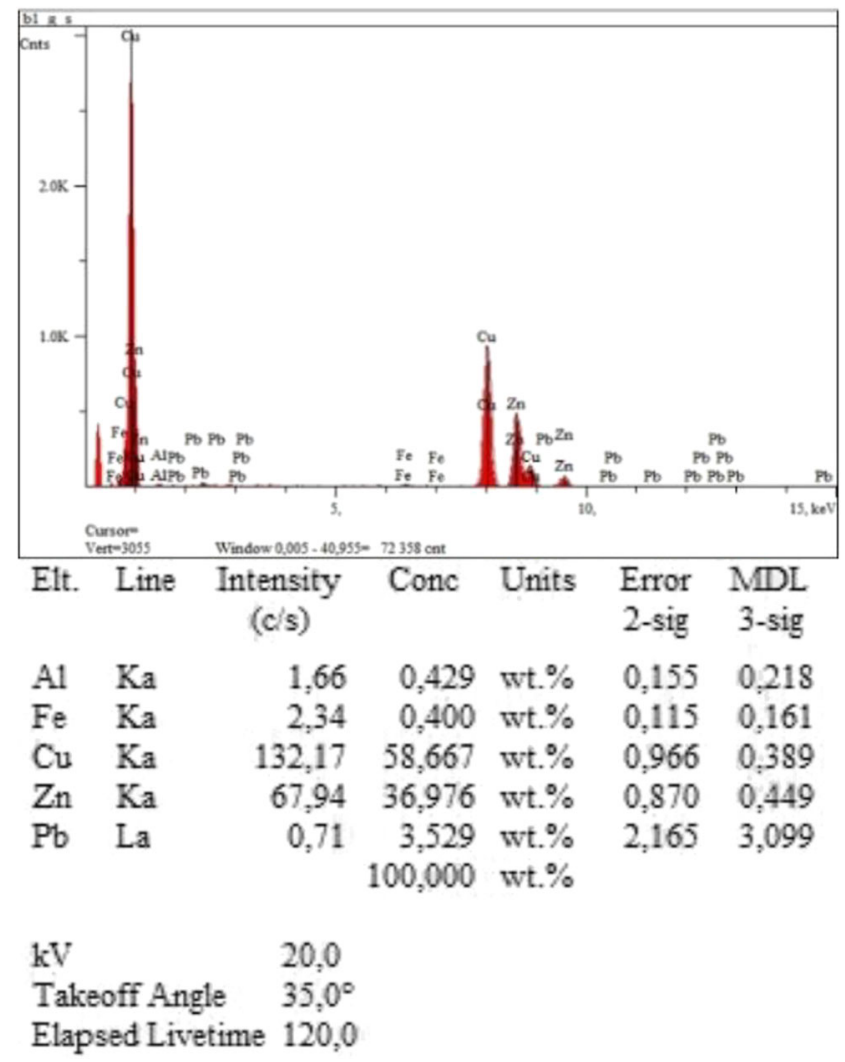

Fig. 7 Analysis of the chemical composition of the sample from smelt $0.1 \%$ flux, zone 1 


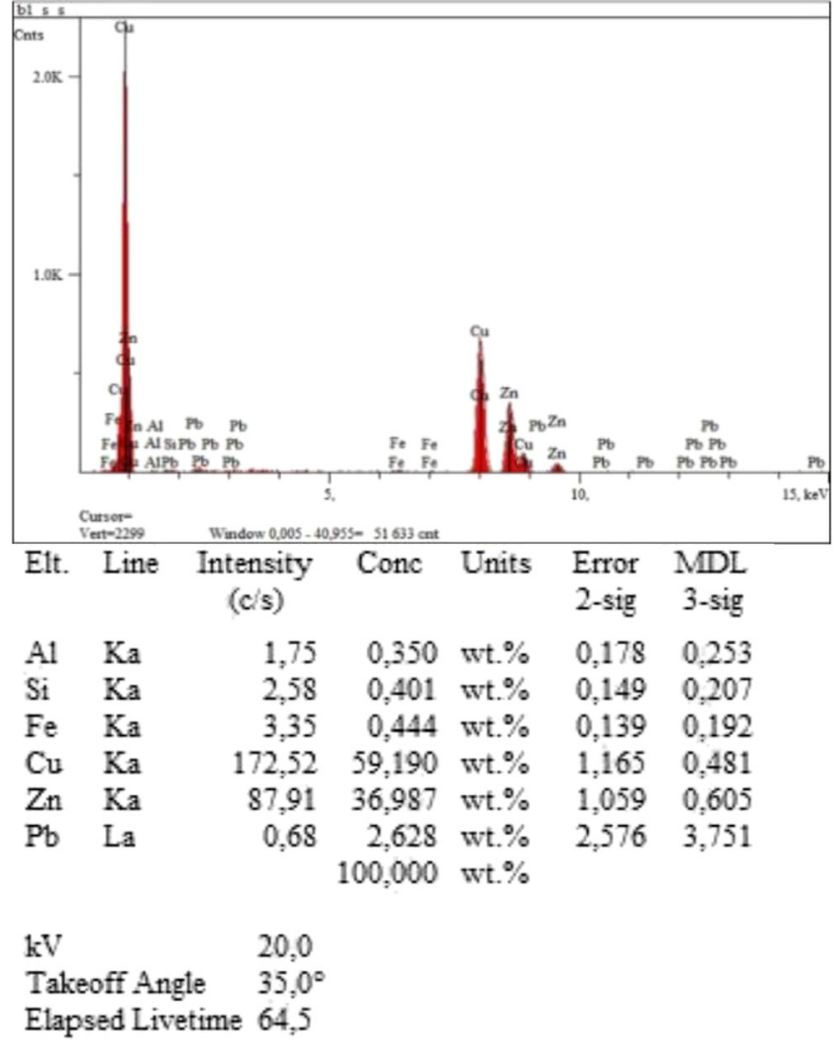

Fig. 8 Analysis of the chemical composition of the sample from smelt $0.1 \%$ flux, zone 2

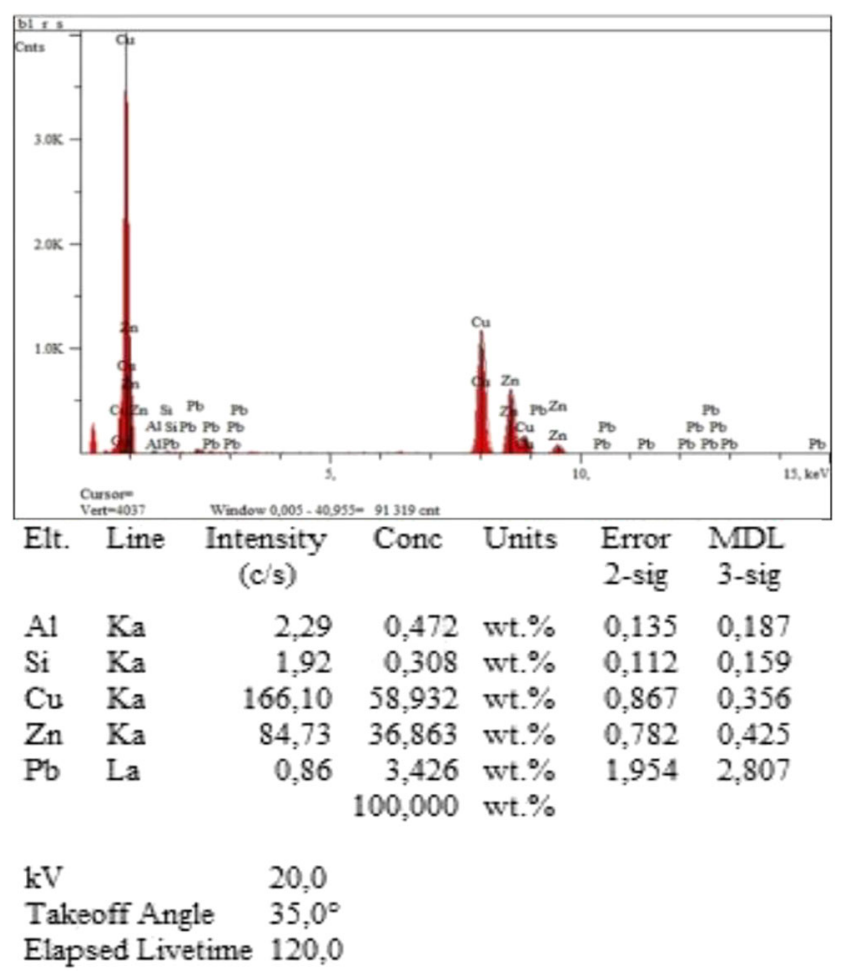

Fig. 9 Analysis of the chemical composition of the sample from smelt $0.1 \%$ flux, zone 3

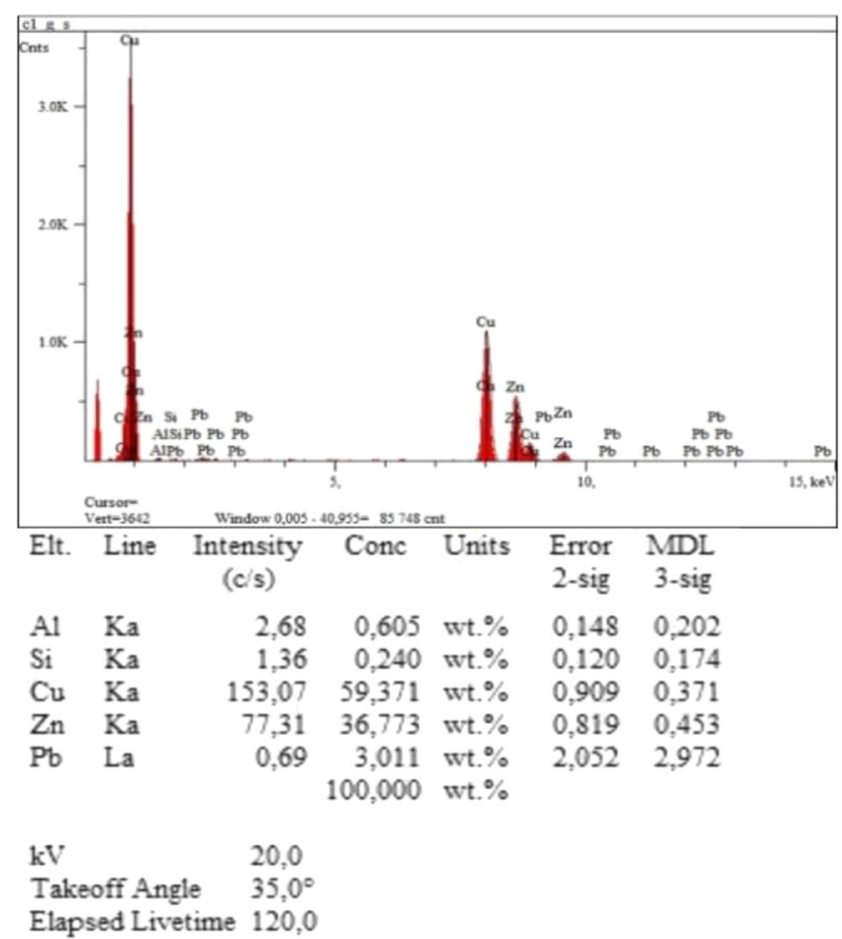

Fig. 10 Analysis of the chemical composition of the sample from smelt $0.15 \%$ flux, zone 1

consists of the solid solution $\alpha$, phase $\beta^{\prime}$ and lead removals.

Analysing the photos in the table, it can be noticed that the refining process has an impact on a

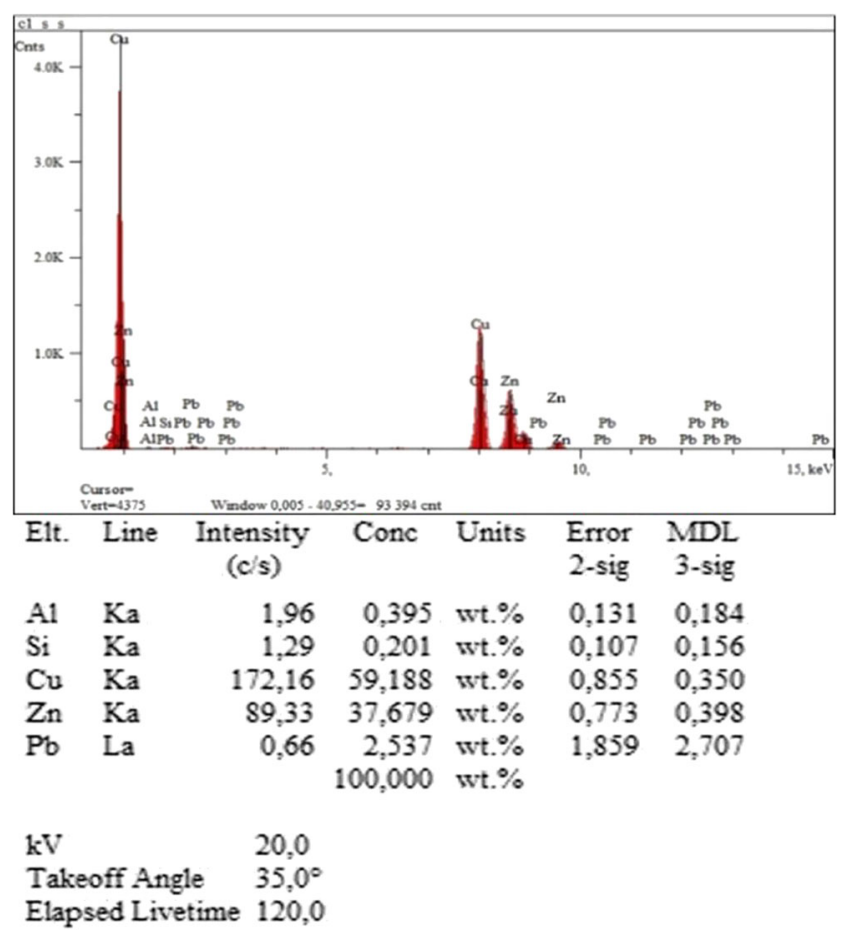

Fig. 11 Analysis of the chemical composition of the sample from smelt $0.15 \%$ flux, zone 2 


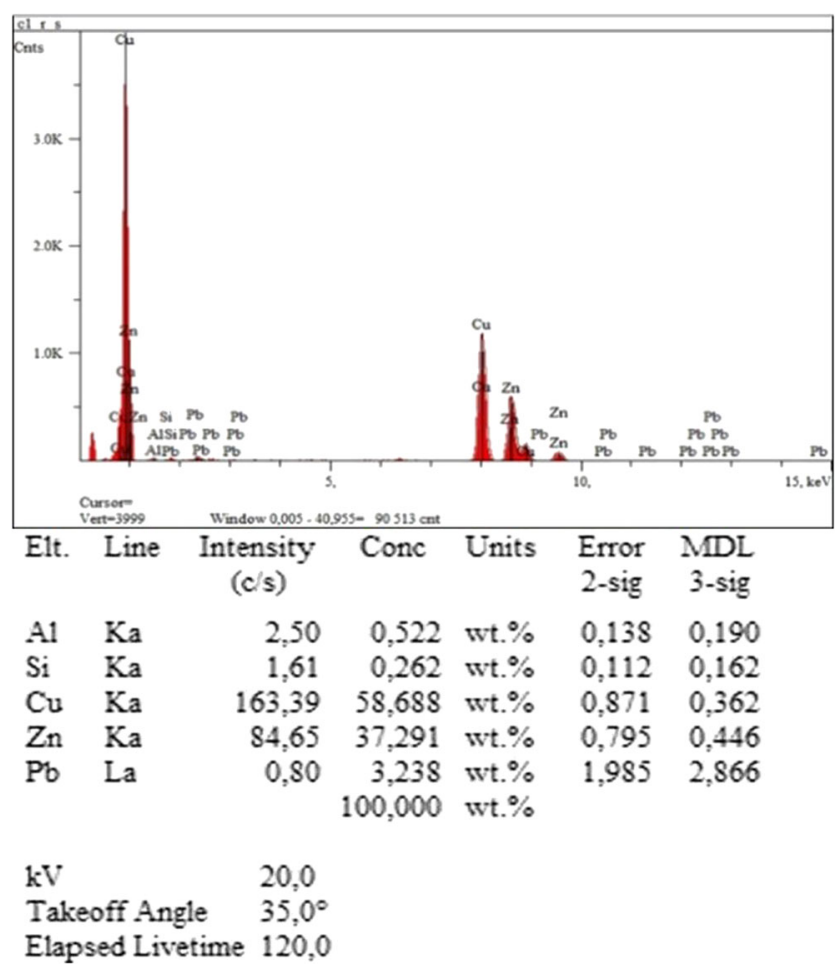

Fig. 12 Analysis of the chemical composition of the sample from smelt $0.15 \%$ flux, zone 3

microstructure of the brass $\mathrm{CuZn} 39 \mathrm{~Pb} 2$ such as changes in a size of solid solution $\alpha$ removals, phase $\beta$ ' and a removals size as well as the arrangement of the lead. Using Topbal $\mathrm{Z}$ flux in the refining process results in the structure homogenisation.

The differences in the structure of individual alloys disappear below zone 3 . Therefore, further research and their analysis were carried out only in zones $1-3$.

Visible changes of the microstructure can be observed for zone $2(0.15 \%$ Topbal $Z)$ whereas in zones 3-6 the structure is homogenous (anisotropic crystals). On the observed metallographic microsections, it may

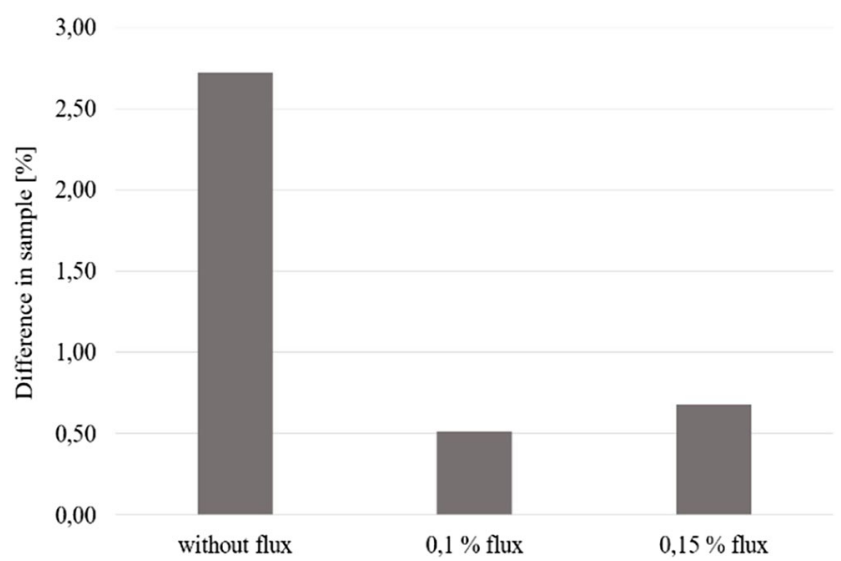

Fig. 13 The percentage difference in the elements $\mathrm{Cu}$ in the samples examined

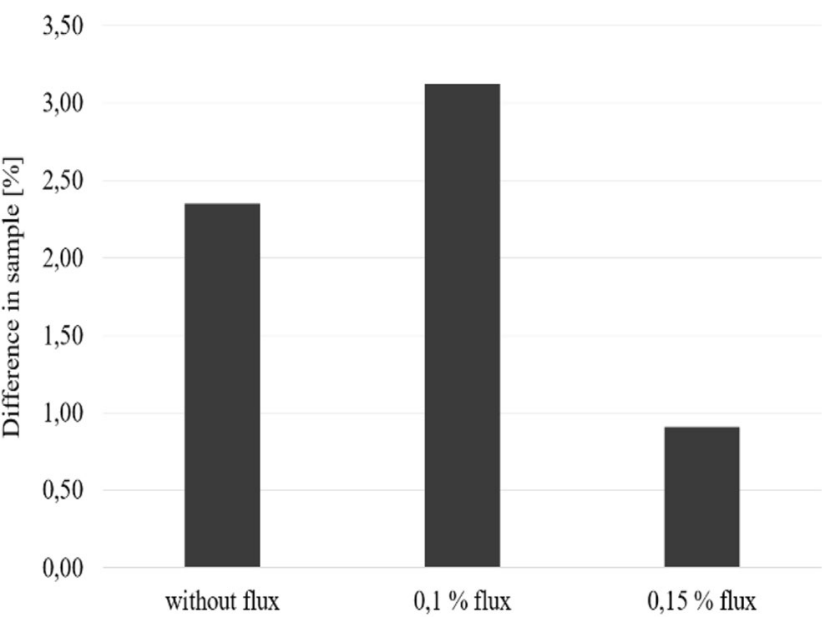

Fig. 14 The percentage difference in the elements $\mathrm{Zn}$ in the samples examined

be noticed that the solid solution $\alpha$ removals and phases $\beta$ ' have mixed. The lead removals are seen as tiny and dark, arranged evenly in the entire volume of the analysed zones, not creating clusters on the border of the solid solution $\alpha$ and phase $\beta$ '. In the alloy which has not been refined, there are lead removals creating clusters on the border of the solid solution $\alpha$ and phase $\beta$, which has a negative impact on the mechanical properties of the alloy. The growth of the flux concentration influences the increase of the solidifed crystals layer's volume, which significantly increases the hardness of the surface layer.

The analysis of the chemical composition the samples has been presented in Figs. 4-12.

The percentage difference in the basic alloy elements for particular smelts, for the samples from different areas of the ingot, has been presented in Figs. 13-15.

1,40

1,20

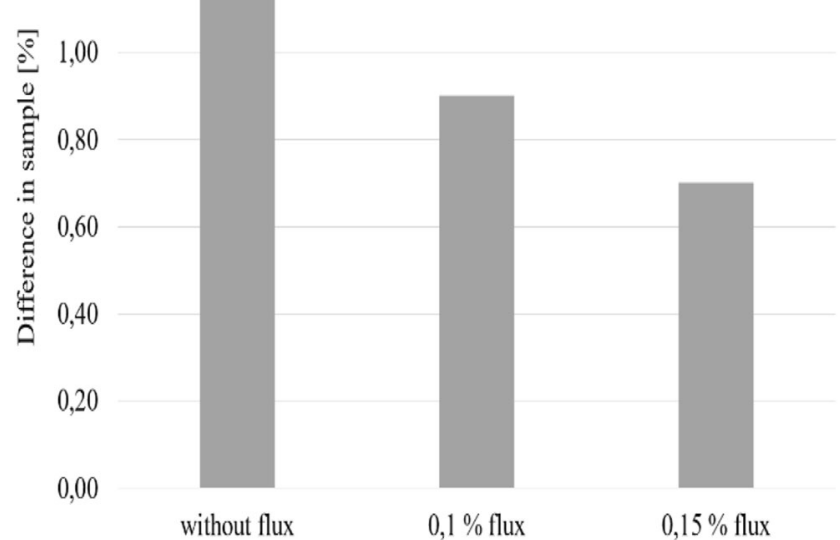

Fig. 15 The percentage difference in the elements $\mathrm{Pb}$ in the samples examined 


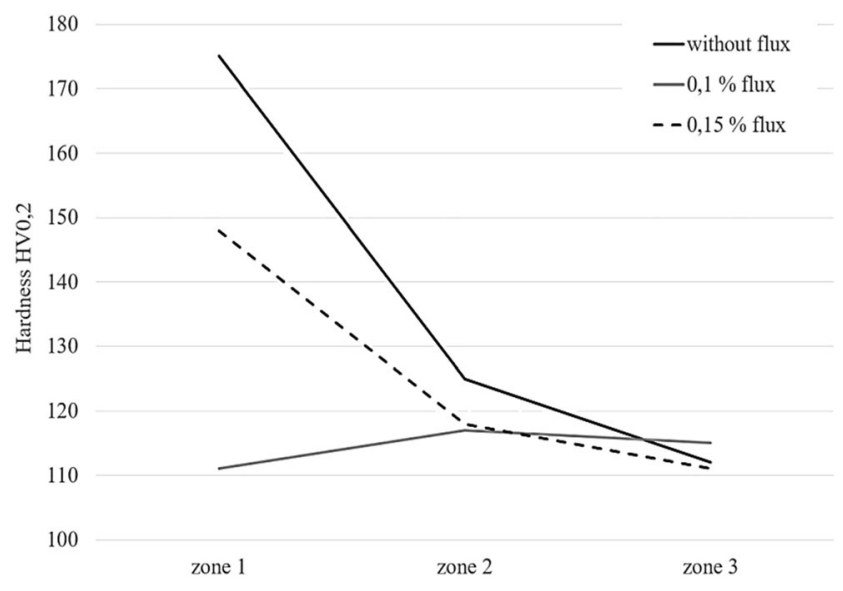

Fig. 16 The results of measuring the hardness of the samples from particular zones, depending on the smelting conditions

As shown in the pictures above, the alloy refining contributed to the increase of the chemical composition stability in the entire volume of the ingot. The closest to the normative and the most stable chemical composition has been reached for the flux added to the smelt in the concentration of $0.15 \%$.

The hardness of the particular samples has been measured, and the results have been shown in Fig. 16.

As seen in Fig. 16, in zone 1, there is an essential difference in the hardness of the samples from different smelts. The highest hardness in this zone, discovered in the sample cast without the flux, was caused by the increased thickness of the solidifed crystals zone. The increased hardness in the zone of the casting skin (the surface zone of the cast) can result, in case of mechanical processing, in a faster cutting tool wear. In the rest of the zones considered, the hardness values have not shown any significant differences.

The results of the strength tests have been presented in Fig. 17.

On the basis of the data received by the tensile testing, it may be stated that materials emerged in the refining process are characterised by higher strength parameters. The differences in the parameters of the strength properties for the samples from the smelting with the use of the flux are insignificant. However, they are noticeably higher than parameters for the sample created without any modification.

\section{Conclusions}

As a conclusion from the research done, what must be highlighted is the significant and positive impact of the Topbal $\mathrm{Z}$ flux on the refining process and received metallographic structures, characterised by higher homogeneity and grain refinement. Its optimal concentration is $0.1 \%$. Above this concentration, the changes described are less significant. The refining contributed also to an improvement of mechanical properties by increasing the strength of the alloys received as a result of the refining. Taking the further alloys mechanical processing into consideration, modifying the alloy with the flux concentration $0.1 \%$ of the kiln charge has proven to be the most favourable. The surface layer expansion, characterised by higher hardness which may result in the increased cutting tool wear, has not been observed at this concentration.
Fig. 17 The results of the strength tests for the samples from particular smelts
60

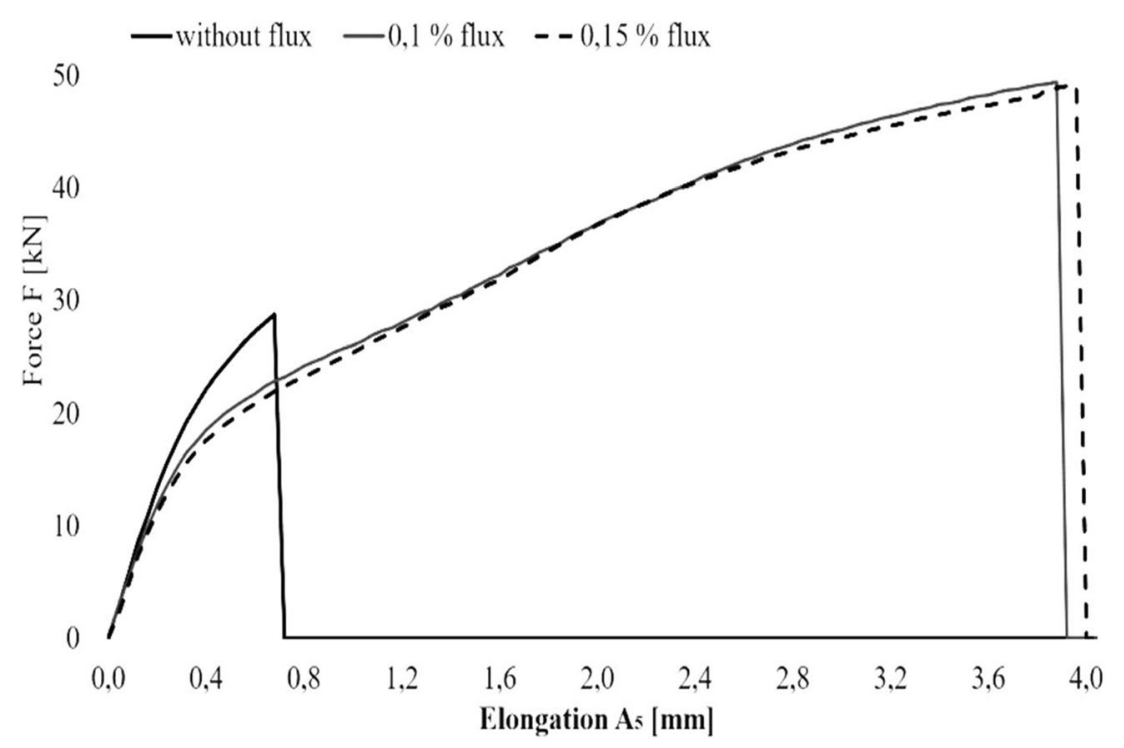


Author contribution Paweł Schlafka: conceptualization, methodology, investigation, formal analysis, writing - original draft, writing - review and editing, visualization. Mariusz Jenek: writing - review and editing, supervision.

Funding M.R.D., K.K.D., and W.W. acknowledge the financial support from the program of the Polish Minister of Science and Higher Education under the name "Regional Initiative of Excellence" in 2019-2022, project no. 003/RID/2018/19.

Availability of data and material Not applicable

\section{Declarations}

Ethics approval and consent to participate All authors certify that they have no affiliations with or involvement in any organization or entity with any financial interest or non-financial interest in the subject matter or materials discussed in this manuscript. The authors give their consent for publication.

\section{Consent for publication Not applicable.}

Competing interests The authors declare no competing interests.

Open Access This article is licensed under a Creative Commons Attribution 4.0 International License, which permits use, sharing, adaptation, distribution and reproduction in any medium or format, as long as you give appropriate credit to the original author(s) and the source, provide a link to the Creative Commons licence, and indicate if changes were made. The images or other third party material in this article are included in the article's Creative Commons licence, unless indicated otherwise in a credit line to the material. If material is not included in the article's Creative Commons licence and your intended use is not permitted by statutory regulation or exceeds the permitted use, you will need to obtain permission directly from the copyright holder. To view a copy of this licence, visit http://creativecommons.org/licenses/by/4.0/.

\section{References}

1. Bydałek AW (1993) Próba analizowania zdolności rafinacyjnych reduktora w warunkach topienia mosiądzów. Arch Technologii Maszyn i Automatyzacji 12:7

2. Bydałek AW, Bydałek A (2014) The results of the brass refining process in the reducer conditions. Arch Foundry Eng 14(1):21-24

3. Momeni A, Ebrahimi GR, Faridi HR (2015) Effect of chemical composition and processing variables on the hot flow behavior of leaded brass alloys. Mater Sci Eng A 626:1-8, ISSN 0921-5093. https://doi.org/10.1016/j.msea.2014.12.016

4. Kondracki M, Gawrońsk J, Szajnar J, Grzelczak R, Podsiadł K (2002) badanie procesu krystalizacji mosiądzu ołowiowego Mo59 przy pomocy ATD. Arch Foundry 2(4) Nr 4 PAN - Katowice.

5. Rzadkosz S, Zych J, Garbacz-Klempka A, Kranc M, Kozana J, Piękoś M, Kolczyk J, Jamrozowicz Ł (2015) Copper alloys in investment casting technology. Metalurgija. 54(1):293-296

6. Schlafka P, Bydałek AW, Holtzer M, Wołczyński W (2016) The influence of the ionic reactions on the refining secondary raw materials. Metalurgija 55(4):609-612

7. Blaz L, Konior Z, Majda T (2001) Structural aspects of $\alpha / \beta$ transformation in hot deformed CuZn-39Pb3 alloy. J Mater Sci 36(15): 3629-3363, ISSN: 00222461. https://doi.org/10.1023/A: 1017988725494

8. F. Romankiewicz, (1983) Modyfikacja miedzi i jej niektórych stopów w warunkach procesu metalurgicznego, Monografia nr 20, WSI Zielona Góra.

9. Romankiewicz F (2000) Modyfikacja miedzi i jej stopów, Komisja Nauki o Materiałach PAN Oddział w Poznaniu. Politechnika Zielonogórska, Zielona Góra

10. Sharififar M, Akbari Mousavi SAA (2014) Tensile deformation and fracture behavior of $\mathrm{CuZn} 5$ brass alloy at high temperature. Mater Sci Eng A 594(31):118-124, ISSN 0921-5093. https://doi.org/10. 1016/j.msea.2013.11.051

11. Bougoffa MSE, Bachir bey MN, Benouali C et al (2021) Dry Sliding friction and wear behavior of $\mathrm{CuZn39Pb} 2$ and AA7075 under industrial and laboratory conditions. J Bio Tribo Corros 7: 38. https://doi.org/10.1007/s40735-021-00475-x

Publisher's note Springer Nature remains neutral with regard to jurisdictional claims in published maps and institutional affiliations. 